UDK: 343.211(4-672EU)

Originalan naučni rad

Biblid: 1451-3188, 20 (2021)

Primljen 31. 10. 2021.

God XX, br. 76, str. 81-97

Odobren 8.11.2021.

DOI: https://doi.org/10.18485/iipe_ez.2021.20.76.6

\title{
SMETNJE ZA IZVRŠENJE EVROPSKOG NALOGA ZA HAPŠENJE I PREDAJU
}

\begin{abstract}
Milijana BUHA*
Apstrakt: Okvirnom odlukom o evropskom nalogu za hapšenje i predaju uvodi se jedan novi oblik međunarodne krivičnopravne pomoći u Evropskoj uniji, lišen tradicionalnih prepreka u postupku izručenja. Postupak predaje traženih lica u Evropskoj uniji sprovodi se u skladu sa principom uzajamnog priznanja i izvršenja sudskih odluka u krivičnopravnoj oblasti. Apsolutna smetnja u postupku predaje traženih lica je osuđujuća presuda. Osuđujuća presuda kao meritorna sudska odluka je jedna od procesnih garancija osuđenom licu prema načelu ne bis in idem. Princip ne bis in idem je u funkciji zaštite osuđenog ili oslobođenog lica od ponovnog suđenja za isto djelo. Okvirnom odlukom princip ne bis in idem je „oskrnavljen”, jer su samo osuđujuće presude apsolutna smetnja za predaju traženog lica, dok su oslobađajuće presude relativna smetnja za predaju traženog lica. Koliko je smisleno status samo relativne smetnje dati pravnosnažno osuđujućoj presudi, s obzirom na cilj principa međusobnog povjerenja i priznanja sudskih odluka u krivičnopravnoj oblasti.
\end{abstract}

Ključne riječi: predaja, ne bis in idem, zastarjelost, dvostruka inkriminacija

\section{1) UVOD}

Evropski nalog za hapšenje i predaju je novi institut u oblasti međunarodne krivičnopravne pomoći, koji teži da zamjeni tradicionalni postupak izručenja učinilaca krivičnih djela. Ovim institutom uvodi se postupak predaje učinioca krivičnog djela, koji je lišen brojnih ograničenja i prepreka na putu saradnje među državama u borbi protiv prekograničnog kriminaliteta ili krivičnih djela sa elementom inostranosti. U Okvirnoj odluci, zavisno od vrste sudske odluke, načelu

\footnotetext{
* Pravni fakultet Univerzitet u Banjoj Luci, Banja Luka. E-mail: milijana.buha@pf.unibl.org
} 
ne bis in idem se daje svojstvo obligatorne ili fakultativne prepreke u postupku predaje učinioca krivičnog djela državi koja traži izvršenje evropskog naloga. ${ }^{1}$ Prema Okvirnoj odluci iz $2002 .^{2}$ godine nije moguća predaja traženog lica ako postoji osnovana sumnja da je nalog izdat radi progona i kažnjavanja nekog lica zbog pola, rase, vjere, etničkog porijekla, nacionalnosti, političkih mišljenja ili seksualne orijentacije, ili radi izvršenje naloga na štetu traženog lica. Riječ je o takozvanoj diskriminatorskoj klauzuli koja onemogućava predaju traženog lica, jer je obligatorna prepreka u postupku izvršenja evropskog naloga za hapšenje i predaju. ${ }^{3}$

Prema članu 1 stav 1 Okvirne odluke, evropski nalog za hapšenje definiše se kao sudska odluka donesena od strane jedne države članice radi lišavanja slobode i predaje traženog lica drugoj državi članici radi krivičnog gonjenja, izvršenja kazne zatvora ili mjere bezbjednosti. Evropski nalog za hapšenje je prvi korak ka zaživljavanju načela uzajamnog priznanja sudskih odluka u krivičnopravnoj oblasti. Okvirna odluka se smatra kamenom temeljcem sudske saradnje između država članica Evropske unije, što doprinosi stvaranju evropskog prostora slobode, bezbjednosti i pravde. ${ }^{4}$ Primjenom evropskog naloga za hapšenje i predaju u postupku predaje, komunikacija među državama u cilju predaje traženog lica odvija se neposredno između nadležnih pravosudnih organa država.

U preambuli Okvirne odluke utvrđuje se da je osnovni preduslov za uspješnu primjenu evropskog naloga za hapšenje, postojanje visokog stepena povjerenja među državama članicama Evropske unije. Primjena evropskog naloga za hapšenje i predaju može biti suspendovana samo u slučaju ozbiljnog i stalnog kršenja nekog od principa iz člana 6 stav 1 Ugovora o Evropskoj uniji. Evropski nalog za hapšenje i predaju ima za cilj da istovremeno i ubrza, a i pojednostavi postupak predaje odbjeglih izvršilaca krivičnih djela, kao i da osigura zaštitu prava traženog lica. Da li je moguć balans između brzog i jednostavnog postupka predaje, a i zaštite ljudskih prava i sloboda. Radi dostizanja balansa između brzine i jednostavnosti, a kako se ne bi ugrozila ljudska prava, neophodno je osigurati isti obim procesnih prava osumnjičenih, optuženih u krivičnom postupku u bilo kojoj zemlji članici Evropske unije. ${ }^{5}$

\footnotetext{
${ }^{1}$ Milijana Lepir, „Evropski nalog za hapšenje novi institut u oblasti međunarodne krivičnopravne pomoći u prostoru Evropske unije”, Pravna riječ, Banja Luka, 2013, str. 731-746.

2 "Council Framework Decision 2002/584/JHA of 13 June 2002 on the European arrest warrant and the surrender procedures between Member States"; amending act: Framework Decision 2009/299/JHA, Official Journal, L 190, 18 July 2002.

${ }^{3}$ Aleksandra Čavoški, „Evropski nalog za hapšenje”, Evropsko zakonodavstvo, broj 9/10, str. 187-188.

${ }^{4}$ Božidar Banović, „Evropski nalog za hapšenje kao oblik međunarodne krivičnopravne pomoći", Pravni sistem Srbije i standardi EU i Savjeta Evrope, Beograd, 2009, str. 166-167.

${ }^{5}$ John A.E Vervaele, "The transnational ne bis in idem principle in the EU, Mutual recognition and equivalence protection of human rights", Utrecht Law Review, Vol. 1, Issue 2, 2005, pp. 100-118.
} 
Osnovna prepreka za priznanje i izvršenje stranih sudskih odluka u krivičnopravnoj oblasti je nepostojanje ujednačenih standarda o pravima osumnjičenih odnosno optuženih u krivičnom postupku. U cilju prevazilaženja ovog problema Evropska komisija je usvojila Green Paper on Procedural Safeguards for Suspect and Defendants in Criminal Proceedings Throughout the EU (Zelena knjiga o zaštiti proceduralnih prava osumnjičenih i optuženih u krivičnim postupcima širom Evropske unije). ${ }^{6}$ Zelena knjiga je samo jedan od koraka u izgradnji jedinstvenog standarda prava osumnjičenih ili optuženih u krivičnom postupku i nema obavezujuću pravnu snagu za zemalje članice Evropske unije.

\section{2) SMETNJE ZA IZVRŠENJE EVROPSKOG NALOGA ZA HAPŠENJE I PREDAJU}

Prepreke za izvršenje evropskog naloga za hapšenje i predaju možemo podijeliti na obavezne i fakultativne prepreke u postupku predaje traženog lica. Kada se utvrdi da postoji neka od apsolutnih smetnji za izvršenje evropskog naloga nemoguće je provesti postupak predaje, dok fakultativne prepreke mogu biti smetnja za predaju, ali ne moraju, zavisi od volje države izvršioca evropskog naloga.

\subsection{APSOLUTNE SMETNJE ZA PREDAJU TRAŽENOG LICA}

Član 3 Okvirne odluke predviđa tri razloga kao apsolutne smetnje za izvršenje Evropskog naloga za hapšenje i predaju, a to je načelo ne bis in idem ${ }^{7}$ koje je limitirano u smislu da je apsolutna smetnja za predaju traženog lica samo osuđujuća presuda, ali pod uslovom da je izrečena kazna izdržana ili je u toku postupak izdržavanja izrečena kazne ili je nastupila zastarjelost izrečene kazne; amnestija (koja se cijeni prema pravu države izvršioca naloga), i godine života traženog lica (ako je riječ o licu koje prema pravu države izvršioca naloga ne može biti krivično odgovorno za djela koja mu se stavljaju na teret).

Ako je krivično djelo za koje je izdat evropski nalog predmet amnestije u državi izvršenja naloga i nadležna je ta država za krivično gonjenje krivičnog djela u

\footnotetext{
${ }^{6}$ Green Paper from the Commission Procedural Safeguards for Suspects and Defendants in Criminal Proceeding Troughout the EU, Brussels, COM, 2003, 75 final. Zelena knjiga je skup prava priznatih osumnjičenom, odnosno optuženom prema Evropskoj konvenciji o zaštiti ljudskih prava i osnovnih sloboda i Povelji o osnovnim pravima Evropske unije. Osumnjičeni, odnosno optuženi ima pravo na pravično suđenje, prevodioca ukoliko ne razumije jezik na kojem se vodi krivični postupak protiv njega, pravo na pravnu pomoć tokom postupka, kao i da bude upoznat sa pravima koja mu pripadaju u postupku koji se vodi protiv njega.

${ }^{7}$ Više o načelu: Milijana Buha, Ne bis in idem u kaznenim postupcima, Pravni fakultet Univerziteta u Banjoj Luci, 2021. str. 8-13.
} 
skladu sa svojim pravom, razlog je za obavezno odbijanje izvršenja naloga. Amnestija je obligatorna prepreka za predaju traženog lica ako su kumulativno ispunjena dva uslova da je to krivično djelo amnestirano u državi izvršenja evropskog naloga i da ista ta država ima nadležnost za krivično gonjenje prema svom krivičnom zakonodavstvu. Činjenica da je amnestija akt zakonodavnog organa, koji znači predavanje u zaborav nekog krivičnog djela kao da nikada nije ni izvršeno i pri tome se ne zna koji će sve izvršioci krivičnog djela biti obuhvaćeni ovim aktom, čini opravdanim tretiranje amnestije kao apsolutne smetnje za izvršenje evropskog naloga. Pojedine države ne poznaju amnestiju kao institut ${ }^{8}$ koji sprečava preduzimanje procesnih radnji protiv amnestiranog lica za amnestirano djelo, ova apsolutna smetnja za izvršenje evropskog naloga se cijeni prema pravu države izvršenja naloga.

Apsolutna smetnja za izvršenje evropskog naloga za hapšenje i predaju su i godine starosti traženog lica. Značajan razlog za odbijanje izvršenja evropskog naloga je ako se radi o licu koje po pravu države izvršenja naloga zbog svog uzrasta nije sposobno da snosi odgovornost za krivično djelo koje mu se stavlja na teret. U Evropskoj uniji postoje velike razlike u pogledu starosne granice odgovornosti za krivično djelo, po pitanju uzrasta učinioca djela u vrijeme izvršenja krivičnog djela u smislu da je lice sposobno da odgovara, jer je krivo za djelo koje je protivpravno i propisano u zakonu kao krivično djelo. U nekim od država EU kao što su Austrija, Italija, Njemačka ta je granica 14 godina, Belgiji čak 18, Grčkoj 13, Danskoj 15, u Engleskoj i Velsu 10, 12, 15 zavisno od kategorije krivičnog djela, a u Sjevernoj Irskoj samo 10 godina. ${ }^{9}$

Još jedna od prepreka za izvršenje evropskog naloga za hapšenje i predaju je osuđujuća presuda za traženo lice u nekoj od država članica Evropske unije, ali da se izrečena kazna izdržava ili je izdržana kazna ili kazna ne može biti izvršena, tj. nastupila je zastarjelost za izvršenje izrečene kazne prema pravu države u kojoj je izrečena. Godine starosti traženog lica su prepreka za izvršenje evropskog naloga za predaju ako traženo lice ne može krivično odgovarati prema pravu države izvršenja evropskog naloga zbog svoje životne dobi. U našem krivičnom pravu ${ }^{10}$ nije isključena ni krivična odgovornost maloljetnika. Stoga, da li je moguća i predaja maloljetnih ili nije.

\footnotetext{
${ }^{8}$ Aleksandra Čavoški, Mario Reljanović, Pravosuđe i unutrašnji poslovi u Evropskoj uniji, „Službeni glasnik”, Beograd, 2009, str.150.

${ }^{9}$ Milan Škulić, Maloletničko krivično pravo, Pravni fakultet Univerziteta u Beogradu i „Službeni glasnik", Beograd, 2012, str. 72-273.

${ }^{10}$ Krivični zakonik Republike Srpske, „Službeni glasnik Republike Srpske”, br. 64/17.
} 


\subsubsection{Dejstvo načela ne bis in idem prema okvirnoj odluci o evropskom nalogu za hapšenje i predaju}

Često se u teoriji susrećemo sa tezom da je apsolutna smetnja za izvršenje evropskog naloga za hapšenje i predaju načelo ne bis in idem. ${ }^{11}$ Međutim, Okvirnom odlukom se samo snaga apsolutne smetnje daje jednoj vrsti sudske odluke da je presuđena stvar (res iudicate), a to je pravnosnažno osuđujuće presude i to kojom je izrečena kazna, dok u pogledu drugih sudskih odluka oslobađajuće presude ili presude kojom se optužba odbija daje snaga relativne prepreke u postupku izvršenja evropskog naloga.

U Evropskoj uniji pravosudna saradnja u krivičnopravnoj oblasti dobija sve značajniju ulogu, jer se želi stvoriti prostor u kome vlada princip pravne sigurnosti i jednakosti građana EU u svim državama članicama Evropske unije. Razvijanje saradnje u ovoj oblasti prava moguće je ukoliko se usvoji i prihvati jedinstven stav o dejstvu principa ne bis in idem, tj. da li se odnosi na pravnosnažne meritorne sudske odluke (u smislu da li se odnosi samo na presude (osuđujuću i/ili oslobađajuću), ili i na neke druge meritorne sudske odluke). S obzirom na postojanje drugačijih zakonskih rješenja u krivičnopravnoj oblasti među državama članicama Evropske unije, koliko je lako provodiv princip međusobnog povjerenje i priznanja sudskih odluka u krivičnopravnoj oblasti, jer znače prihvatanje prava država da imaju drugačije zakone. Jedan od bitnijih instrumenata u krivičnopravnoj oblasti, pomoću kojeg se želi omogućiti da sudske odluke jedne države članice EU proizvodne pravno dejstvo i u drugoj državi članici EU, je evropski nalog za hapšenje i predaju. ${ }^{12}$ Prema članu 54 Konvencije o implemetaciji šengenskog sporazuma ${ }^{13} \mathrm{i}$ članu 50 Povelje Evropske unije ${ }^{14} \mathrm{o}$ osnovnim pravima prepreka za ponovno suđenje istog lica za isto djelo su meritorne sudske odluke, oslobađajuća i osuđujuća presuda. ${ }^{15}$ Navedene odredbe pomenutih konvencija na prostoru Evropske unije eksterno dejstvo priznaju, ne samo osuđujućoj presudi nego i oslobađajućoj, dok to nije baš tako prema odredbama Okvirne odluke o apsolutnim i relativnim smetnjama za izvršenje evropskog naloga.

${ }^{11}$ Vojislav Đurđić, „Evropski nalog za hapšenje”, Zbornik radova Pravnog fakulteta u Novom Sadu, 1/2012, str. 31-37.

${ }^{12}$ John A. E. Vervaele, "The transnational ne bis in idem principle in the EU, Mutual recognition and equivalence protection of human rights", op. cit., p. 103; Martin Wasmeier, "The principle of ne bis in idem", International Review of Penal Law, Vol. 1, Issue 2, 2006, p. 120

${ }^{13}$ Konvencija o implementaciji šengenskog sporazuma, „Službeni list Evropske unije”, L 239/19.

${ }^{14}$ Povelja Evropske unije o osnovnim pravima, „Službeni list Evropske unije”, C 202/389.

${ }^{15}$ Milijana Lepir, Ekstradicija u savremenom pravu, (magistarska teza), Pravni fakultet Univerziteta u Banjoj Luci, 2013, 87-90. 
Načelo ne bis in idem ima značajnu ulogu u procesu jačanja međunarodne saradnje u krivičnopravnoj oblasti, jer odluka o priznanju strane sudske odluke je još uvijek stvar diskrecionog ovlašćenja države koja odlučuje o priznanju i izvršenju te odluke. Poteškoće u primjeni i tumačenju ovog načela su utoliko veće što ne postoji jedinstvena definicija ovog načela. Evropska unija, kao zajednica koja ne poznaje granice, nameće potrebu definisanja i određivanja dejstva ovog načela unutar prostora Unije kao unificiranog pravnog poretka. ${ }^{16} \mathrm{U}$ pogledu određivanja dejstva načela ne bis in idem na prostoru Evropske unije značajna je odluka Evropskog suda pravde u slučaju Gözutök i Brügge. Da li su obligatorna ili fakultativna prepreka za izvršenje evropskog naloga za hapšenje i predaju samo meritorne ili i formalne odluke suda, Evropski sud pravde je zauzeo stav u slučaju Gözutök i Brügge. ${ }^{17} \mathrm{U}$ pomenutom slučaju, sporno je bilo da li je odluka tužioca o obustavljanju krivičnog gonjenja u jednoj od zemalja članica EU, obavezujuća i za drugu zemlju članicu. Evropski sud pravde je u vezi sa spornim pitanjem zauzeo stav da je i formalna odluka donesena u jednoj zemlji članici EU, obavezujuća i za druge zemlje članice. ${ }^{18}$ Priznavanjem eksternog dejstva i sudskim i tužilačkim odlukama u krivičnom postupku na prostoru Evropske unije, ${ }^{19}$ razumljivo je ako polazimo od teze da je cilj evropskog naloga za hapšenje i predaju da zaživi saradnja među državama članica Unije i u krivičnopravnoj oblasti u skladu sa principom uzajamnog priznanja i povjerenje sudskih odluka.

Na prostoru Evropske unije načelo ne bis in idem ima transnacionalnu dimenziju, jer se prvenstveno razmatra kroz prizmu prava na slobodu kretanja ljudi i dobara na integrisanom prostoru Evropske unije, a istovremeno je nužno osigurati građanima visok stepen sigurnosti u skladu sa članom 29 Ugovora o osnivanju Evropske unije. ${ }^{20}$ Ovo načelo je definisano u Povelji o osnovnim pravima Evropske unije kao zaštitno pravo pojedinca ${ }^{21} \mathrm{i}$ opseg primjene načela ne bis in

\footnotetext{
${ }^{16}$ Milijana Buha, Ne bis in idem u kaznenim postupcima, Pravni fakultet Univerziteta u Banjoj Luci, 2021. str. 158-195.

${ }^{17}$ European Court of Justice, Joined cases C-187/01 and C385/01, Judgment of the Court of 11 February 2003.

${ }^{18}$ Valsamis Mitsilegas, "The Constitutional Implications of Mutual Recognition in Criminal Matters in the EU", Common Market Law Review, vol. 43, Kluwer Law International, Netherlands 2006, pp. 1300-1304; John A. E. Vervaele, "The transnational ne bis in idem principle in the EU. Mutual recognition and equivalent protection of human rights", op. cit., pp. 100-118.

${ }^{19}$ Vidi više o kontroli tužilačkih odluka: Vanja Bajović, „O položaju oštećenog u krivičnom postupku", Pravni život, br. 9, str. 543-562.

${ }^{20}$ Elizabeta Ivičević - Karas, „Načelo ne bis in idem u evropskom kaznenom pravu”, Hrvatski ljetopis za kazneno pravo i praksu, vol. 21, No. 2, 2014, 271-294.

${ }^{21}$ Roland Michael Kniebühler, Transnationales 'ne bis in idem', Duncker \& Humblot, Berlin, 2005, p. 314 .
} 
idem proširen je na nivo Evropske unije, a ne samo u okvirima nacionalne jurisdikcije. Rekli bismo da je težnja da se načelu ne bis in idem prizna eksterno dejstvo na prostoru Evropske unije.

Kada posmatramo načelo ne bis in idem u granicama Okvirne odluke, rekli bismo da ovom odlukom dejstvo načela ne bis in idem, u smislu da li ima eksterno ili interno dejstvo i da li je apsolutna ili relativna smetnja za izvršenje evropskog naloga, zavisi od vrste presude - da li je riječ o osuđujućoj presudi, oslobađajućoj ili presudi kojom se optužba odbija. Jedna od relativnih prepreka za izvršenje evropskog naloga je i činjenica da su pravosudna tijela odustala od krivičnog gonjenja. Kada se u Okvirnoj odluci govori o odustanaku pravosudnih organa od krivičnog gonjenja, da li se misli samo na sudove ili i na tužilaštva kao državnog organa koji je i stranka u postupku bez čijih procesnih radnji preduzetih radi pokretanja i vođenja krivičnog postupka u konačnici nema ni sudskih odluka. ${ }^{22}$ Tako da, kada se vratimo na odluku pravosudnih organa kojom se odustaje od krivičnog gonjenja nameće se kao pitanje da li se misli samo na sudsku odluku kojom se optužba odbija ili i na odluku tužioca o obustavi krivičnog postupka. Shodno iznesenim zapažanjima, pitanje je da li je tužilačka odluka o odustanku od krivičnog gonjenja relativna smetnja za izvršenje evropskog naloga za hapšenje i predaju.

Prema Okvirnoj odluci rekli bismo da je eksterno dejstvo, u smislu apsolutne smetnje za izvršenje evropskog naloga, priznato samo pravnosnažno osuđujućoj presudi kojom je izrečena kazna, a ne upozoravajuće sankcije i to pod uslovom da je započeto sa izvršenjem izrečene kazne. Prepreka za izvršenje evropskom nalogu ne bi bila osuđujuća presuda, ukoliko nisu ispunjena još dva kumulativno propisana uslova u članu 3 stava 2 Okvirne odluke, a to je da je osuđujućom presudom izrečena kazna i izdržava se izrečena kazna ili je nastupila zastarjelosti za izvršenje izrečene kazne osuđujućom presudom. Osuđujuća presuda donesena u nekoj trećoj državi, koja nije članica Evropske unije, ima status relativne smetnje za izvršenje evropskog naloga, jer je fakultativna prepreka za izvršenje evropskog naloga. Tačke 5 stav 1 člana 4 Okvirne odluke govori o pravnosnažno osuđujućoj presudi izrečenoj u trećoj državi kao fakultativnoj prepreci za izvršenje evropskom nalogu. Kao fakultativne prepreke za izvršenje evropskog naloga navodi se odustajanje pravosudnih organa od krivičnog gonjenja. Nameće nam se pitanje -

${ }^{22} \mathrm{U}$ okvirnoj odluci se pominju pravosudni organi, pa nam se kao pitanje nameće da li je pravosudni organ samo sud ili se misli i na sud i tužilaštva. U našem pravu Bosne i Hercegovine status pravosudnih organa imaju samo sudovi. Nužnost postojanja identiteta između optužbe i presude u krivičnom postupku ukazuje da sudskih odluka nema bez tužilačkih. Tako da bismo mogli izvesti zaključak da se možda misli i na meritorne tužilačke odluke. Napominjemo da se u tački 3 stava 1 člana 4 Okvirne odluke propisuju fakultativne smetnje, tj. relativne smetnje za izvršenje evropskog naloga i koristi imenica u množini pravosudnih organa. 
kakva je to sudska odluka kojom se odustaje od krivičnog gonjenja, da li je to naredba o obustavi istrage protiv koje se može uložiti žalba, a o kojoj odlučuje sud, ili je to presuda kojom se optužba odbija jer je tužilac odustao od optužbe, a oštećeni nije preuzeo zastupanje optužnice? ${ }^{23}$

Načelo ne bis in idem znači nemogućnost ponovnog suđenja istom licu za isto djelo. Prema Okvirnoj odluci nije apsolutna smetnja za izvršenje evropskog naloga oslobađajuća presuda i presuda kojom se optužba odbija. Presuda kojom se optužba odbija je fakultativna prepreka za izvršenje evropskog naloga i time se ovoj sudskoj odluci priznaje rekli bismo interno dejstvo u Evropskoj uniji. Postavlja se pitanje koliko je zaista Okvirnom odlukom napravljen iskorak ka međusobnom priznanju sudskih odluka u krivičnopravnoj oblasti, ukoliko se govori o apsolutnim i relativnim smetnjama za izvršenje naloga i ako meritorne odluke nisu apsolutna smetnja za izvršenje evropskog naloga.

Članom 4 stava 1 tačke 3 Okvirne odluke propisano je da je fakultativna prepreka i izrečena pravnosnažna presuda koja sprečava dalje krivično gonjenje istog lica za isto djelo. Rekli bismo da se u ovom slučaju misli na pravnosnažno oslobađajuću presudu kao fakultativnu prepreku u izvršenju evropskog naloga za hapšenje i predaju. Neki od razloga koji opravdavaju identifikovanje oslobađajuće presude kao fakultativne prepreke za izvršenje evropskog naloga za hapšenje i predaju su što oslobađajuća presuda zbog nedostatka dokaza može da bude donesena radi nemara ili pasivnog držanja organa gonjenja, pa i suda u krivičnom postupku, ${ }^{24}$ a onda zakonom je isključeno da ovakvi propusti budu naknadno identifikovani u sudskoj odluci i sankcionisani donošenjem druge sudske odluke. ${ }^{25}$ Opasnost od priznavanja apsolutnog dejstva i pravnosnažnoj oslobađajućoj presudi je što ista može da egzistira nauštrb istine, ako nije dozvoljena upotreba vanrednog pravnog lijeka na štetu oslobođenog. Jedan od razloga za donošenje presude kojom se optuženi oslobađa od optužbe je da djelo za koje je lice optuženo nije zakonom propisano kao krivično djelo, što je osnov principa dvostruke inkriminacije koji nije obligatorna prepreka za izvršenje evropskog naloga i kada je riječ o pravnosnažnoj oslobađajućoj presudi. Kada je riječ o okolnostima koje

\footnotetext{
${ }^{23}$ Milijana Buha, „Procesna prava oštećenog prema Zakonu o krivičnom postupku Republike Srpske iz 2020", Jedanaesta međunarodna naučno-stručna konferencija krivično zakonodavstvo i prevencija kriminaliteta (norma i praksa), Srpsko udruženje za krivičnopravnu teoriju i praksu, Ministarstvo pravde Republike Srpske, 2020, str. 479-491.

${ }^{24}$ Milijana Buha, Ne bis in idem u kaznenim postupcima, op. cit., str. 40-42.

${ }^{25}$ Milan Škulić, „Načelo pravičnog vođenja krivičnog postupka i načelo istine u krivičnom postupku”, Pravni život, I tom 9/2010, str. 593-594; Milan Škulić, „Načelo istine i osnovna dokazna pravila u novom zakonu o krivičnom postupku Srbije", Pravna riječ, Časopis za pravnu teoriju i praksu, Banja Luka 2013, str. 491-507.
} 
isključuju krivičnu odgovornost, razlog za donošenje oslobađajuće presude nije na isti način definisano u svim državama članicama Unije.

S druge strane, ima mjesta razmišljanju da se i pravnosnažno oslobađajućoj presudi prizna eksterno dejstvo, posebno kada je ista donesena jer postoje okolnosti koje isključuju krivičnu odgovornost i time se ova presuda svrstava u grupu apsolutnih smetnji za izvršenje evropskog naloga za hapšenje, što je i u interesu pravne sigurnosti, a ne postoji obaveza država članica Evropske unije da u potpunosti usklade svoje krivično zakonodavstvo. ${ }^{26}$

Presuda kojom se optužba odbija, ili kako se još u teoriji ova vrsta presuda imenuje kao procesna presuda ili presuda donesena iz formalnih razloga, je fakultativna prepreka za izvršenje evropskog naloga za hapšenje i predaju. Neki od razloga zbog kojih se donosi presuda kojom se optužba odbija su: ako je tužilac odustao od optužbe, ako je postupak pravnosnažnim rješenjem obustavljen, ako je nastupila zastarjelost krivičnog gonjenja, ako je tužilac odustao od krivičnog gonjenja. S razlogom smo se opredijelili da pomenemo ove razloge kao osnov za donošenje presude kojom se optužba odbija, jer ove razloga uočavamo kao fakultativnu prepreku za izvršenje evropskog naloga za hapšenje i predaju, tačka 3 i 4 stava 1 člana 4 Okvirne odluke.

\section{3) RELATIVNE SMETNJE U POSTUPKU PREDAJE TRAŽENOG LICA}

Fakultativne prepreke za izvršenje evropskog naloga za hapšenje i predaju su: ako djelo nije inkriminisano (priniple of daoube criminality) kao krivično djelo i prema pravu države izvršenja evropskog naloga, ali pod uslovom da nije riječ o krivičnim djelima pobrojanim u članu 1 stava 1 Okvirne odluke u pogledu kojih se ne traži ispunjenje uslova dvostruke inkriminacije; ako je pokrenut postupak za traženo lice u državi izvršenja naloga i to zbog istog djela koje je predmet evropskog naloga, tj. litispendentio; ako su pravosudni organi države izvršenja naloga odustali od krivičnog gonjenja za krivično djelo koje je predmet evropskog naloga ili je izrečena pravnosnažna presuda u nekoj od država članica za krivično djelo koje je obuhvaćeno evropskim nalogom; ako je nastupila zastarjelost krivičnog gonjenja ili izvršenja kazne i to prema pravu države izvršenja naloga i da je država izvršenja naloga nadležna za krivično gonjenje; ako je evropski nalog izdat radi izvršenja izrečene kazne, a traženo lice se nalazi na teritoriji države izvršenja naloga ili je državljanin države izvršenja evropskog naloga, s tim da se izvršenje kazne provodi u skladu sa pravom države izvršenja naloga; ako je

${ }^{26}$ Branko Rakić, „Princip supsidijarnosti i raspodele nadležnosti između Evropske unije i država članica", Pravni život, br. 12, 1995, str. 603-623. 
krivično djelo u potpunosti ili djelimično izvršeno na teritoriji države izvršenja evropskog naloga ili je krivično djelo djelimično učinjeno na teritoriji države izvršenja naloga ili na mjestu koje se smatra da pripada toj državi i ako je krivično djelo učinjeno van državnog područja države izdavaoca naloga, a pravo države izvršenja naloga ne omogućava krivično gonjenje za krivična djela počinjena van njenog područja.

Smetnje za izvršenje evropskog naloga koje su definisane kao fakultativne prepreke nisu u skladu sa načelom pravne sigurnosti optuženih i osuđenih u krivičnom postupku, jer od volje država članica, tj. države izvršenja naloga zavisi da li će cijeniti neku prepreku kao smetnju za izvršenje evropskog naloga ili ne. Državljanstvo je i dalje smetnja, ali relativna za izvršenje evropskog naloga ako se kazna zatvora ili pritvor već sprovodi u državi izvršenja protiv lica koje ima državljanstvo ili prebivalište u državi izvršenja. Principom jednakog tretmana domaćih državljana sa državljanima drugih država članica Unije, Evropski sud pravde se rukovodio u predmetu Wolzenburg, ${ }^{27}$ tako da razlog za odbijanje izvršenja evropskog naloga može biti kako državljanstvo tako i stalno prebivalište. Zanimljivo je primijetiti da je na spisku fakultativnih smetnji za izvršenje evropskog naloga i oslobađajuća presuda donesena u nekoj trećoj državi koja nije članica Evropske unije. Vrlo su moguće situacije da lice ima državljanstvo neke treće države koja nije članica Evropske unije i stalno prebivalište u državi izvršenja evropskog naloga, pa se kao pitanje nameće da li će fakultativna prepreka za izvršenje evropskog naloga radi izdržavanja izrečene kazne zatvora ili mjere lišavanja slobode biti prepreka i za lice koje ima stalno prebivalište u državi izvršenja naloga, a nije državljanin neke od država članica Evropske unije.

Zaštita ljudskih prava nije u katalogu ni apsolutnih ali ni relativnih smetnji za izvršenje evropskog naloga. Osnov za odbijanje izvršenja evropskog naloga za hapšenje je povreda ljudskih prava u Velikoj Britaniji. ${ }^{28}$ Pitanjem značaja ljudskih prava kao smetnje u postupku predaje traženih lica bavio se Evropski sud pravde u nekim slučajevima kao što su Radu, ${ }^{29}$ Melloni. ${ }^{30}$ U predmetu Radu Sud je pažnju posvetio povredi prava traženog lica na saslušanje u državi izdavaocu naloga i zauzeo stav da nije bilo povrede prava, kao i da ne postoji mogućnost proširivanja razloga za odbijanje izvršenja evropskog naloga. Sud je stava da klauzula zaštite ljudskih prava ne smije da ugrozi postupak predaje traženog lica, jer bi se usporio i učinio neefikasnim postupak predaje traženih lica. Prednost je data principu

\footnotetext{
${ }^{27}$ C-123/08Wolzenburg [2009] ECR I-9621.

${ }^{28}$ Catherine Heard, Daniel Mansell, "The European Arrest Warrant: The role of judges when Human Rights are at risk", New Journal of European Criminal Law, vol. 2/ 2011, pp. 353-367.

${ }^{29}$ Case C-396/11, Radu, ECJ, 29 January 2013.

${ }^{30}$ Case C-399/11, Melloni, ECJ, 26 February 2013.
} 
uzajamnog priznanja u odnosu na zaštitu ljudskih prava. U slučaju Melloni Evropski sud pravde razmatrao je da li je opravdano odbiti predaju traženog lica ako prijeti opasnost od suđenja u odsustvu, što je suprotno pravu na pravično suđenje. Slično kao i u predmetu Radu Sud u slučaju Melloni nije odstupao od principa uzajamnog povjerenja i priznanja sudskih odluka, koji dominira u odnosu na druge pravne standarde koji su garant pravičnog suđenja. Restriktivno tumačenje Okvirne odluke nije izostalo ni u predmetu Jeremy $F^{31}$ u kome Sud ističe da pravni lijek suspenzivnog dejstva protiv odluke o izvršenju evropskog naloga nije sporan ako je u saglasnosti sa rokovima propisanim Okvirnom odlukom, što je teško zamislivo.

Postupak predaje traženih lica koji je uveden Okvirnom odlukom u Evropskoj unije je strogo kruto postavljen. Evropski sud pravde je prepoznat kao zaštitnik strogog formalističkog postupka koji „slijepo" i jedino slijedi princip međusobnog povjerenja i priznanja sudskih odluka koji je osnov za provođenje postupka predaje. Primjedbe koje se mogu staviti na račun provođenja postupka predaje jesu da je u dobroj mjeri zanemarena zaštita osnovnih procesnih prava traženih lica. U tom smislu nailazimo i na primjedbe da princip uzajamnog priznanja ne smije da znači povredu osnovnih ljudskih prava, kao i da bi se tekst Okvirne odluke trebao usaglasiti sa praksom Evropskog suda za ljudska prava. ${ }^{32}$ Ukoliko postoje dokazi da prijeti opasnost od kršenja osnovnih ljudskih prava traženog lica, država izvršenja naloga trebalo bi da zatraži određene garancije od države izdavaoca naloga da traženo lice neće biti uskraćeno za osnovna procesna prava koja su garant poštovanja i osnovnih ljudskih prava u krivičnom postupku protiv njega.

U red relativnih smetnji za predaju traženog lica ubraja se državljanstvo i teritorijalni princip. Država izvršenja evropskog naloga može da odbije izvršenje naloga ako je krivično djelo u potpunosti ili djelimično izvršeno na teritoriji države izvršenja evropskog naloga, čime se i dalje ne zanemaruje teritorijalni princip kao primarni u važenju krivičnog zakonodavstva jedne države. Država izvršenja naloga slijedeći teritorijalni princip, kao primarni princip, ima pravo da odbije izvršenje naloga ako krivično djelo nije izvršeno na teritoriji države izdavaoca naloga, a prema pravu države izvršenja naloga krivično gonjenje za krivično djelo koje je predmet naloga nije moguće ako je izvršeno van teritorije države izvršenja naloga. Relativna smetnja za izvršenje evropskog naloga je državljanstvo traženog lica ako je evropski nalog izdat radi izvršenja kazne zatvora ili pritvora, a traženo lice ima državljanstvo ili stalno prebivalište u državi izvršenja naloga. S tim da državljanstvo neće biti ni relativna smetnja za izvršenje evropskog naloga ako je isti izdat radi krivičnog gonjenja traženog lica. Razlog radi koga državljanstvo ne može biti smetnja za izvršenje evropskog naloga radi krivičnog gonjenja traženog lica

\footnotetext{
${ }^{31}$ Case C-168/13 PPU, Jeremy F, ECJ, 30 May 2013.

${ }^{32}$ Sandra Stojković, Uzajamno priznanje odluka u krivičnim stvarima i prava okrivljenog lica, Univerzitet u Novom Sadu, Pravni Fakultet, doktorska disertacija, 2016, str. 89-94.
} 
nalazimo u činjenici da je cilj evropskog naloga da spriječi da učinioci prekograničnog kriminaliteta ostanu nekažnjeni. Međutim, zanimljivo je primjetiti da prema teritorijalnom principu kao primarnom u važenju krivičnog zakonodavstva, iako je svrstan u skup relativnih smetnji za predaju traženog lica, traženo lice ostane nekažnjeno za djelo koje mu se stavlja na teret, ako je riječ o krivičnom djelu koje je u potpunosti ili djelimično izvršeno na teritoriji države izvršenja naloga.

\section{4) PRINCIP DVOSTRUKE INKRIMINACIJE/KAŽNJIVOSTI I ZASTARJELOST}

Princip dvostruke inkriminacije prema članu 2 stava 2 Okvirne odluke nije ni apsolutna ni relativna smetnja za izvršenje evropskog naloga u pogledu krivičnih djela pobrojanih u ovoj odredbi. Ukidanjem principa dvostruke inkriminacije u odnosu na navedena krivična djela u prethodno pomenutoj odredbi znači ograničenje primjene materijalnog krivičnog prava države izvršenja naloga. Prema članu 2 stava 4 Okvirne odluke principu dvostruke inkriminacije se daje status relativne smetnje za izvršenje evropskog naloga kada je riječ o krivičnim djelima koja nisu pobrojana u tački 2 ovog člana. Princip dvostruke inkriminacije se ne može posmatrati odvojeno od principa zakonitosti, što čini upitnim legitimnost zahtjeva za ubrzavanjem međunarodne saradnje ukidanjem principa dvostruke inkriminacije kao tradicionalne prepreke u postupcima međunarodne krivičnopravne pomoći. Ukidanje principa dvostruke inkriminacije je suprotno načelu pravne sigurnosti lica koja žive u Evropskoj uniji, jer može biti predato drugoj državi za djelo koje nije krivično djelo u državi u kojoj se nalazi traženo lice. Ovakvim postupanjem se krši načelo legaliteta..$^{33}$ Članom 2 stava 2 Okvirne odluke navedena su djela u pogledu kojih se ne utvrđuje princip dvostruke inkriminacije, iako u pogledu ovih krivičnih djela ne postoji usaglašena pravna definicija. ${ }^{34}$ Jedno od krivičnih djela koje je navedeno u prethodno pomenutoj odredbi jeste i terorizam, gdje radnje izvršenja ovog djela za neke može biti odbrambeni čin a za neke terorizam. Nabrajanjem krivičnih djela u pogledu kojih se odstupa od principa dvostruke kažnjivosti može se posmatrati kao poseban uslov u smislu težine krivičnih djela. Mora da se radi o krivičnim djelima u pogledu kojih je u državi koja je izdala evropski nalog propisana kazna zatvora od najmanje tri godine. ${ }^{35}$ Princip

\footnotetext{
${ }^{33}$ Vojislav Đurđić, op. cit., str. 29-30.

${ }^{34}$ Massimo Fichera, The implementation of the European Arrest Warrant in the European Union: law, policy and practice, PhD thesis - University of Edinburgh, School of Law, 2009, p. 102; Bedanna Bapuly, The European Arrest Warrant under Constitutional Attack, ICL Journal, Vol 3, 1/2009, 4, pp. 4-26, preuzeto sa www.icl-journal.com, dostupno 30. 9. 2021.

${ }^{35}$ Milan Škulić, Međunarodno krivično pravo, Univerzitetu u Beogradu - Pravni fakultet, Centar za izdavaštvo, 2020, str. 543-548.
} 
dvostruke inkriminacije nije apsolutna smetnja u postupku predaje traženih lica u Evropskoj uniji, ako su kumulativno ispunjena dva uslova propisana u članu 2 stava 2 Okvirne odluke da je riječ o nekom od krivičnih djela pobrojanih u ovom članu i da je krivično djelo za koje se može izreći kazna zatvora od tri godine ili više prema pravu države koja izdaje evropski nalog.

U teoriji krivičnog prava iznose se zapažanja da se princip dvostruke inkriminacije ne može odvojeno posmatrati od zastare u smislu da ne postoji obaveza utvrđivanja da li je djelo zastarjelo, ako je riječ o krivičnom djelu koje je obuhvaćeno u stavu 2 člana 2 Okvirne odluke. Zagovornici teze da je zastarjelost neodvojiva od dvostruke inkriminacije/kažnjivosti, polaze od činjenice da je evropski nalog izdat u odnosu na krivična djela u pogledu kojih se ne ispituje dvostruka kažnjivost, pa samim time i ne postoji obaveza ni utvrđivanja da je zastarjelo takvo krivično djelo. Zapravo, polazi se od teze da krivična djela u pogledu kojih se ne ispituje uslov dvostruke inkriminacije i zastarevanja se ne utvrđuje, jer je sadržana u pojmu dvostruke kažnjivosti. ${ }^{36}$ Dok, s druge strane, zastarjelost se može posmatrati kao samostalni institut, jer se i članom 4 stava 1 tačke 4 Okvirne odluke govori o zastarjelosti kao relativnoj smetnji za izvršenje evropskog naloga. Tako da zastarjelost kao negativnu smetnju za izvršenje strane sudske odluke treba ispitati u odnosu na svako krivično djelo, tako i ona djela koja su obuhvaćena članom 2 stava 2 Okvirne odluke. Stoga, zastarjelost kao samostalni institut mora da se ispita u odnosu na svako krivično djelo.

Rasprave u hrvatskoj stručnoj javnosti o odnosu dvostruke kažnjivost i zastarjelosti su posebno eskalirale kada je Njemačka izdala nalog za hapšenje hrvatskih državljana umješanih u ubistvo Stjepana Đurekovića, osamdesetih godina prošlog vijeka u Njemačkoj. ${ }^{37}$ Evropski sud pravde u slučaju Gasparini $i^{38}$ zauzeo je stav da je zastarjelost apsolutna smetnja za izvršenje evropskog naloga za hapšenje i predaju.

Mišljenja smo da institut zastarjelosti treba posmatrati kao samostalni institut od principa dvostruke kažnjivosti. Zastarjelost je nesporno relativna smetnja za izvršenje evropskog naloga za hapšenje prema članu 4 stava 1 tačke 4 Okvirne odluke. Zastarjelost krivičnog gonjenja je samo relativna smetnja za izvršenje evropskog naloga, iako o nastupanju zastarjelosti krivičnog gonjenja odlučuje sud po službenoj dužnosti (prema našem pravu), ${ }^{39}$ a ista bi trebala da proizvodi i pravno

\footnotetext{
${ }^{36}$ Davor Derenčinović, „Doseg isključenja provjere dvostruke kažnjivosti iz Zakona o pravosudnoj saradnji u kaznenim stvarima sa državama članicama Evropske unije", Hrvatski ljetopis za kaznenom pravo i praksu, Zagreb, vol. 21, br. 2/2014, str. 249-270.

${ }^{37}$ Davor Derenčinvić, op. cit., str. 251-252.

${ }^{38}$ Case C-467/04 Gasparini [2006] ECR I-9199, §31.

${ }^{39}$ Odluku o nesporvođenju istrage radi nastupanja zastarjelosti krivičnog gonjenja prema članu 242 stava 3 Zakona o krivičnom postupku Republike Srpske donosi tužilac. S tim da presudu
} 
dejstvo na teritoriji neke druge države članice Unije. Zastarjelost izvršenja izrečene kazne je prema članu 3 stava 2 Okvirne odluke apsolutna smetnja ako se izrečena kazna ne može izvršiti prema pravu države izvršenja naloga. Okvirnom odlukom se pravi distinkcija između zastarjelosti krivičnog gonjenja kao relativne smetnje i zastarjelosti izvršenja izrečene kazne kao apsolutne smetnje za izvršenje evropskog naloga. Imajući u vidu da je zastarjelost krivičnog gonjenja relativna smetnja za krivičnim gonjenjem, onda bi se mogao smatrati legitiman zahtjev za predajom traženog lica radi krivičnog gonjenja iako je nastupila zastarjelost gonjenja. Međutim, ako polazimo od suštine instituta zastarjelosti koji znači trajnu i neotklonjivu procenu smetnju ${ }^{40}$ koji obesmišljava krivično gonjenje, upitna je legitimnost zahtjeva za predaju ako je nastupila zastarjelost krivičnog gonjenja prema pravu države izvršenja naloga. 0 zastarjelosti krivičnog gonjenja kao procesnoj smetnji sud mora da vodi računa po službenoj dužnosti i donese odgovarajuću sudsku odluku zavisno od faze krivičnog postupka. Ako sud države izvršenja naloga ima obavezu da vodi računa o zastarjelosti krivičnog gonjenja po službenoj dužnosti i ima obavezu da donese odgovarajuću sudsku odluku, nameće se pitanje zašto sudska odluka države izvršenja naloga o nastupanju zastarjelosti krivičnog gonjenja se ne priznaje u skladu sa principom međusobnog priznanja i povjerenja sudskih odluka, koji je kamen temeljac sudske saradnje u Evropskoj uniji.

\section{5) ZAKLJUČAK}

Na kraju bi se mogao zauzeti stav da načelo ne bis in idem, u skladu sa odredbama Okvirne odluke, ima eksterno dejstvo među državama članicama Evropske unije ali samo u pogledu osuđujuće sudske odluke. U pogledu oslobađajuće sudske odluke ili formalnih sudskih odluka načelo ne bis in idem ima interno dejstvo u granicama nacionalne jurisdikcije država članica, jer je relativna smetnja za izvršenje evropskog naloga. Mišljenja smo da ima prostora da se i pravnosnažno oslobađajućoj presudi prizna eksterno dejstvo, posebno kada je ista donesena, jer postoje okolnosti koje isključuju krivičnu odgovornost i time bi ova presuda bila prepoznata kao apsolutna smetnja za izvršenje evropskog naloga za hapšenje, a što je u funkciji principa međusobnog priznanja sudskih odluka koji je kamen temeljac prvosudne saradnje u Evropskoj uniji. Nužnost tretiranja

kojom se optužba odbija jer je nastupila zastarjelost krivičnog gonjenja donosi sud, prema članu 297 stav 1 tačka d) Zakona o krivičnom postupku Republike Srpske. Problematično je priznavanja eksternog dejstva odluci tužioca o obustavi istrage, jer je nastupila zastarjelost, jer ista nije podložna sudskoj kontroli. Vidi više o zastarjelosti: Milan Škulić, „Pravna priroda i krivičnopravni (materijalni i procesni) efekt zastarelosti krivičnog gonjenja”, Anali Pravnog fakulteta u Beogradu, godina LXV 1/2017, str. 25-58.

${ }^{40}$ Milan Škulić (2017), op. cit., str. 42. 
oslobađajuće presude kao apsolutne smetnje u postupku predaje proizilazi i iz člana 54 Konvencije o implementaciji šengenskog sporazuma, kao i iz člana 50 Povelje Evropske unije o osnovnim prvima. Zastarjelost krivičnog gonjenja je samo relativna smetnja za izvršenje evropskog naloga, iako o nastupanju zastarjelosti krivičnog gonjenja odlučuje sud po pravilu jer je o istoj dužan da vodi računa po službenoj dužnosti. Stoga, nameće se pitanje zašto se sudska odluka države izvršenja naloga o nastupanju zastarjelosti krivičnog gonjenja ne priznaje u državama članicama Evropske unije, u skladu sa principom međusobnog priznanja i povjerenja sudskih odluka koji je pravna podloga sudske saradnje u Evropskoj uniji. Princip dvostruke inkriminacije nije apsolutna smetnja u postupku predaje traženih lica u Evropskoj uniji, ako su kumulativno ispunjena dva uslova propisana u članu 2 stava 2 Okvirne odluke: da je riječ o nekom od krivičnih djela pobrojanih u ovom članu i da je krivično djelo za koje se može izreći kazna zatvora od tri godine ili više prema pravu države koja izdaje evropski nalog. Susrećemo se sa određenim primjedbama koje su smislene, u pogledu eliminisanja principa dvostruke inkriminacije u ocjeni da li ima mjesta za predaju traženog lica ili ne, jer isto znači povredu načela zakonitosti. Međutim, zanimljivo je spomenuti da se u red relativnih smetnji ubraja i teritorijalni princip važenja krivičnog zakonodavstva, prema kome država izvršenja naloga može odbiti izvršenje istog ako je djelo izvršeno na njenoj teritoriji. Ako bi država izvršenja naloga odbila predaju traženog lica, jer je krivično djelo izvršeno na njenoj teritoriji, ima li obavezu krivičnog gonjenja traženog lica.

\section{6) LITERATURA}

Apap, Joanna, Carrera, Sergion, "Judicial cooperation in Criminal Matters , European Arrest Warrant, A Good Testing Ground for Mutual Recognition in the Enlarged EU?", CEPS Policy Brief, No. 46, 2004, pp. 1-19.

Bajović, Vanja, „O položaju oštećenog u krivičnom postupku”, Pravni život, br. 9, str. 543-562.

Banović, Božidar, „Evropski nalog za hapšenje kao oblik međunarodne krivičnopravne pomoći", Pravni sistem Srbije i standardi EU i Savjeta Evrope, Beograd, 2009, str. 166-167.

Bapuly, Bedanna, "The European Arrest Warrant under Constitutional Attack", ICL Journal, Vol 3, 1/2009, 4, pp. 4-26, preuzeto sa www.icl-journal.com

Buha, Milijana, „Procesna prava oštećenog prema Zakonu o krivičnom postupku Republike Srpske iz 2020", Jedanaesta međunarodna naučno-stručna konferencija krivično zakonodavstvo i prevencija kriminaliteta (norma i praksa), Srpsko udruženje za krivičnopravnu teoriju i praksu, Ministarstvo pravde Republike Srpske, 2020, str. 479-491. 
Buha, Milijana, Ne bis in idem u kaznenim postupcima, Pravni fakultet Univerziteta u Banjoj Luci, 2021.

Čavoški, Aleksandra, Reljanović, Mario, Pravosuđe i unutrašnji poslovi u Evropskoj uniji, Službeni glasnik, Beograd, 2009.

Čavoški, Aleksandra, „Evropski nalog za hapšenje”, Evropsko zakonodavstvo, broj 9/10, 2004, str. 187-188.

Derenčinović, Davor, „Doseg isključenja provjere dvostruke kažnjivosti iz Zakona o pravosudnoj saradnji u kaznenim stvarima sa državama članicama Evropske unije", Hrvatski ljetopis za kaznenom pravo i praksu, Zagreb, vol. 21, br. 2/2014, str. 249-270.

Đurđić, Vojislav, „Evropski nalog za hapšenje”, Zbornik radova Pravnog fakulteta u Novom Sadu, 1/2012, str. 21-38.

Fichera, Massimo, The implementation of the European Arrest Warrant in the European Union: law, policy and practice, $\mathrm{PhD}$ thesis - University of Edinburgh, School of Law, 2009.

Heard, Catherine, Mansell, Daniel, "The European Arrest Warrant: The role of judges when Human Rights are at risk", New Journal of European Criminal Law, vol. 2/ 2011, pp. 353-367.

Ivičević - Karas, Elizabeta, „Načelo ne bis in idem u evropskom kaznenom pravu”, Hrvatski ljetopis za kazneno pravo i praksu, vol. 21, No. 2, 2014, str. 271-294.

Kniebühler, Roland Michael, Transnationales 'ne bis in idem', Duncker \& Humblot, Berlin, 2005.

Lepir, Milijana, Ekstradicija u savremenom pravu, (magistarska teza), Pravni fakultet Univerziteta u Banjoj Luci, 2013.

Lepir, Milijana, „Evropski nalog za hapšenje novi institut u oblasti međunarodne krivičnopravne pomoći u prostoru Evropske unije", Pravna riječ, Banja Luka, 2013, str. 731-746.

Mitsilegas, Valsamis, "The Constitutional Implications of Mutual Recognition in Criminal Matters in the EU", Common Market Law Review, vol. 43, Kluwer Law International, Netherlands 2006, pp. 1300-1304;

Rakić, Branko „Princip supsidijarnosti i raspodele nadležnosti između Evropske unije i država članica", Pravni život br. 12, 1995, str. 603-623.

Škulić, Milan, „Načelo pravičnog vođenja krivičnog postupka i načelo istine u krivičnom postupku", Pravni život, I tom 9/2010, str. 593-594;

Škulić, Milan, „Načelo istine i osnovna dokazna pravila u novom zakonu o krivičnom postupku Srbije", Pravna riječ, Časopis za pravnu teoriju i praksu, Banja Luka 2013, str. 491-507. 
Škulić, Milan, „Pravna priroda i krivičnopravni (materijalni i procesni) efekt zastarelosti krivičnog gonjenja", Anali Pravnog fakulteta u Beogradu, godina LXV 1/2017, str. 25-58.

Škulić, Milan, Maloletničko krivično pravo, Pravni fakultet Univerziteta u Beogradu i „Službeni glasnik”, Beograd, 2012.

Škulić, Milan, Međunarodno krivično pravo, Univerzitet u Beogradu - Pravni fakultet, Centar za izdavaštvo, 2020.

Stojković, Sandra, Uzajamno priznanje odluka u krivičnim stvarima i prava okrivljenog lica, (doktorska disertacija), Univerzitet u Novom Sadu, Pravni Fakultet, 2016.

Vervaele, John A. E., "The transnational ne bis in idem principle in the EU. Mutual recognition and equivalent protection of human rights", Utrecht Law Review, 1(2), 2005, pp. 100-118.

Wasmeier, Martin, "The principle of ne bis in idem", International Review of Penal Law, Vol. 1, Issue 2, 2006, pp. 120-130.

\section{OBSTACLES TO THE EXECUTION OF THE EUROPEAN ARREST WARRANT AND THE SURRENDER}

Summary: The Framework Decision on the European Arrest Warrant introduces a new form of international criminal assistance in the European Union devoid of the traditional obstacles to extradition. The surrender procedure of wanted persons in the European Union is implemented in accordance with the principle of mutual recognition of criminal decisions. An absolute obstacle in the procedure of surrendering the requested person is a conviction judgement. A conviction judgement is one of the procedural guarantees for a convicted person according to the principle of ne bis in idem. The principle of ne bis in idem is in the function of protecting a convicted or acquitted person from retrial for the same act. The framework decision "desecrated" the principle of ne bis in idem because only convictions are an absolute obstacle to the surrender of the requested person, while acquittals are a relative obstacle to the surrender of the requested person. So, it is questionable whether the principle of mutual trust and recognition of court decisions will be a fundamental principle of criminal cooperation in the European Union if the final acquittal is only a relative obstacle in the procedure of surrender of the requested person.

Keywords: surrender, ne bis in idem, obsolescence, double incrimination. 